\title{
THE BUYWELL WAY: SEVEN ESSENTIAL PRACTICES OF A HIGHLY SUCCESSFUL MULTI-CHANNEL E- TAILER
}

\author{
Mary Tate \\ Beverley Hope \\ Brent Coker \\ School of Information Management \\ Victoria University of Wellington \\ mary.tate@vuw.ac.nz \\ beverley.hope@vuw.ac.nz \\ brent.coker@vuw.ac.nz
}

\begin{abstract}
After the dot-com bust there is considerable evidence that multi-channel retailers are more successful than purely on-line retailers. Multi-channel retailing is becoming mainstream and considerable research exists on successful multi-channel strategies. Despite this, some organisations are having more success than others with their multi-channel approach. We talked to the management of one of Australasia's most successful multi-channel apparel and home-ware retailers about the theory and practice of multichannel retailing, with the aim of building on existing theory in multi-channel e-commerce.
\end{abstract}

Keywords Multi-channel, E-commerce strategy, active scanning

\section{INTRODUCTION}

The demise of the dotcom's has shown us the value having a physical retail presence in addition to an Internet presence. Increasingly, these 'click-n-brick' organisations are being supplemented with mail-order catalogues, kiosks, and contact centres to form multi-channel marketing and sales organisations. Shorter product life-cycles, greater product choice, and increased fragmentation of customer segments are driving customers to select channels to suit particular purposes and preferences (Goersch 2002). Research indicates around one third of consumers use a combination of the Internet, catalogues, and stores to do their purchasing. These multi-channel consumers spend more than consumers who purchase only from physical retail stores, and they are more loyal (Forrester 2002; Shop.org 2001).

While there is a growing literature on e-commerce implementation and multi-channel strategy, some companies have clearly been more successful than others. The aim of this research was to study an exemplar organisation, with the aim of extending existing theory in multi-channel e-commerce. The research question is: "What extensions to existing multi-channel e-commerce theory can be made based on an exemplar organisation?"

First we review the literature with respect to existing theory for success factors in multi-channel ecommerce. Next we present the research method and results. The paper concludes with a summary of the findings, implications for future research, and contributions of the paper to research and to practice.

\section{LITERATURE REVIEW}

There has been much research on successful implementation of e-commerce into existing organisations (Barua et al. 2001; Ghoshal et al. 2002; Goersch 2002; Gulati et al. 2002; Steinfield et al. 2002; Weill et al. 2002; Westerman 2002; Willcocks et al. 2001a). Some researchers have approached multi-channel e-commerce research from the perspective of buyer behaviour (Balabanis 
et al. 2001; Kaufman-Scarborough et al. 2002; Reardon et al. 2002), while others have focused on Internet strategy (Porter 2001; Simons et al. 2002). Based on this research we identified a number of success factors that we expected to be significant in our exemplar organisation.

In this section we identify from the literature Success Factors (SFs) for a multi-channel e-commerce strategy. From synthesis of literature discussing e-commerce implementation into the organisation, multi-channel buyer behaviour, and Internet strategy, six initial SFs were discovered: functional integration, channel synergy, brand management, information management, logistics management, and customer management. Following our data gathering, and additional, post-hoc literature review was carried out to further explain our findings and provide additional insights in areas that our case organisation had identified as important to them. As a result of this, an additional SF, active scanning, was added based on marketing literature.

\section{SF1: Functional Integration}

Functional integration refers to the degree to which channels share common organisational resources within a multi-channel environment. For example, channels would share functional departments such as finance, marketing, and logistics. (Barua et al. 2001; Goersch 2002; Lee et al. 2001; Schoenbachler et al. 2002; Steinfield et al. 2002; Willcocks et al. 2001a)

There is a danger that, while achieving operational and marketing efficiencies, functional integration can result in loss of freedom and creativity for business units.(Ghoshal et al. 2002; Gulati et al. 2002; Westerman 2002) One way to prevent this is for business units to also share " emotional integration", that is, to subscribe to a shared identity and meaning (Ghosal et al 2002). This includes a desire to reach common goals supported by a shared organisational philosophy.

In summary, functional integration is the sharing of organisational resources across channels, ideally bound by a shared identity and organisational philosophy. The benefits of functional integration are transferred to the customer through channel synergy.

\section{SF2: Channel Synergy}

Channel Synergy is defined as the degree to which channels consistently provide a seamless communication and purchasing experience for customers. (Kaufman-Scarborough et al. 2002; Porter 2001; Reardon et al. 2002; Schoenbachler et al. 2002; Simons et al. 2002; Steinfield et al. 2002). It implies ease of movement across channels. For example, the Internet becomes another customer contact point to facilitate the overall purchasing experience, regardless of where the final transaction takes place (Goersch, 2002).

A propensity to switch channels creates synchronisation problems for a firm as customers expect to be recognised on each channel. For example, customers buying on the Internet expect to be able to return goods to the physical store. Pricing and inventory information must be consistent across channels (Day et al. 2002). Displaying lower prices on one channel may attract customers to that channel, but it carries the danger of inciting resentment from customers loyal to another channel. By maintaining channel consistency, shoppers are encouraged to stay with the same retailer when they switch channels (Goersch, 2002).

In summary, channel synergy includes seamless purchasing and communications experiences for customers and consistency of pricing across channels.

\section{SF3: Brand Management}

Brand Management within the context of multi-channel e-commerce is defined as a firm's ability to 
reinforce and leverage a consistent brand image across channels. (Bitner et al. 2002; Goersch 2002; Kocas 2003; Willcocks et al. 2001a). Multi-channel firms have a distinct advantage over single channel firms by having more interfaces with customers, allowing increased brand visibility and economies of scale in advertising. The more familiar the customer is with a brand, the lower the perceived risk of purchasing across multiple channels (Schoenbachler et al. 2002). Building a strong service brand requires a track record of delivering on promises, for example, meeting promised delivery times. Reliability across all customer contacts is important, because to the customer, the encounter is the service (Bitner et al. 2000).

In summary, brand management includes portraying a consistent brand image, and a track record of service delivery.

\section{SF4: Information Management}

Information management is defined as the process by which information is collected, stored, analysed, and applied (Willcocks et al. 2001a). Good information management is particularly important in multi-channel firms because of the complexities involved in processing transactions from multiple sources and the need for channel synergy. This requires integration of information systems (Barua et al. 2001; Weill et al. 2002). For B2C business models, integration is needed in three areas: application infrastructure (payment transaction processing), internal and external communications infrastructure, and IT management (Weill et al, 2002).

Investing in an integrated information technology infrastructure allows up-to-date customer data from any channel to be made available through all other channels (Goersch, 2002). Furthermore, it allows organisations to track customer demand, thereby lowering costs and improving efficiency while enabling accuracy and speed of order fulfilment (Lee et al. 2001). Information captured through multi-channel shopping is frequently used as a basis for data mining. Information from click stream data, catalogue addresses, and purchasing information can be used to develop automated customer services such as adaptive profiling, one-to-one marketing techniques, and mass customisation.

In summary, good information management involves keeping information up-to-date and consistent across channels through integrated information systems. Information captured from multi-channel shoppers can be used to develop a range of automated services. Internally, integrated information systems are required to support logistics management.

\section{SF5: Logistics Management}

Logistics in a multi-channel strategy involves the ability to effectively and efficiently fulfil orders arising from multiple sources. Order fulfilment from channels other than a physical retail store is the most expensive and critical operation for multi-channel retailers (Lee et al. 2001; Pyke et al. 2001). The process must be matched to the product, the industry, and the business environment. Large or heavy products sold through channels that require a firm to make delivery put pressure on profit margins. Similarly, delivery of small orders or low value orders can squeeze margins. By contrast, products that can be digitalised such as music and software can be delivered over the Internet at much lower costs than distribution of hard copies.

In summary, logistics management involves the ability to process orders from multiple sources, and to provide an efficient logistics function to manage the cost of delivery. 


\section{SF 6: Customer Management}

Customer management is a firm's ability to manage customer relationships, process customer information, and offer customer service in a manner likely to foster and retain customer loyalty (Barua et al. 2001; Kaufman-Scarborough et al. 2002; Lee et al. 2001; Schoenbachler et al. 2002; Simons et al. 2002). Buywell went beyond the descriptions of best practice customer management in the literature. This led us to carry out a post-hoc literature search to assist in further explaining this dimension, and to propose the additional factor described as "active scanning".

Literature also suggested that there would be particular challenges in customer management, particularly for the remote channels, because Buywell's products are mostly non-commoditised items such as clothing and home-wares. It has been suggested that these products often require personalised selling; the process of identifying customer needs and helping people find products to meet their needs. Lack of opportunity for personal selling is considered a limitation for selling experience goods remotely (Schneider et al. 2001). We were interested in exploring how our case organisation had managed this limitation.

Company profits can be dramatically increased from small increases in customer retention rates (Reichheld, 1996 cited in (Winer 2001)). To increase retention rates, firms must build strong relationships with customers based upon understanding who their customers are and what they want. A multi-channel strategy can provide this information through click stream and catalogue purchasing data. Using this information, organisations are able to offer a high level of service through adaptive profiling and one-to-one marketing techniques. (Willcocks et al. 2001b)

\section{SF 7 Active Scanning}

Our post-hoc literature search found Day's commentary on becoming a "market-driven organisation" using "market sensing" most closely described the practices of Buywell (Day 1994). We were not able to find previous studies that had considered the application of aspects of market sensing in multi-channel e-commerce.

Market-driven organisations are more effective at meeting the needs of customers than non marketdriven competitors. They demonstrate "a superior ability to understand, attract, and retain the most valuable customers within the market" (Day, 1994 p. 39). This provides the firm with more anticipatory capability on market conditions resulting in increased speed in responding to the market. Market Sensing is a distinctive capability of market-driven organisations. Proposed by Day in 1994, before the wide-spread diffusion of the Internet, market sensing is "the ability of a firm to learn from their customers and competitors in order to be able to act on events and trends in current and prospective markets in a deliberate and systematic way" (Day, 1994, p. 43). Two important aspects of market sensing are active scanning and informed imitation. In the case of Buywell, active scanning was particularly evident.

Active scanning allows a firm to capture detailed qualitative information in real time, which enables superior customer service and better alignment of a firm's offerings with customer needs. This involves continuous communication with customers (Day, 1994). Active scanning requires employees be motivated to pass information gathered from customers to management. The types of information valuable to management are complaints, requests for new products or services, and feedback on the consequences of competitor activity. For many firms, this information from frontline employees is blocked (Day, 1994).

In summary, market sensing extends the traditional customer management to include active scanning. This is achieved by continuous communication with customers feeding into strategic decision-making. 
These seven success factors derived from literature: functional integration, channel synergy, brand management, information management, logistics management, customer management and active scanning; are used to anchor the findings of our case study.

\section{RESEARCH METHOD}

This research uses a case study methodology in which theoretical propositions, presented in the form of success factors, are compared with empirical materials collected from the field. This creates a link between theory and empirical data "providing a template against which to compare the results of the study" [pg 50] (Yin 1993). This is important given that there is a significant body of existing literature. This also allows us to make explicit the areas where existing theory can be extended by the findings from the case organisation.

\section{The Case Site}

A single case site is used. The company, which we will call Buywell, is Australasia's largest mail-order apparel firm with operations in New Zealand and, more recently, Australia. Buywell is a privately owned company with approximately 650 employees serving 230,000 customers. Initially, the firm sold only women's apparel and only through mail order catalogues. More recently the product range has expanded to include men's and boys' wear, lingerie, footwear, house-ware, and oversized clothing, but women's apparel still accounts for most of Buywell's sales. Their multi-channel strategy now includes mail-order catalogue, contact centre, Internet website, and five physical retail stores located across the North Island of New Zealand. Buywell.

Most of Buywell's customers shop remotely through catalogues or the contact centre. Between nine and eleven catalogues are mailed out each year, and most catalogue-based orders are received within twenty days of each new issue. The website has shown steady growth since its inception in 1998, accounting for $2 \%$ of sales by 2001 and $7 \%$ in 2003 .

Buywell were selected for this research for three reasons. Firstly, Buywell has been very successful, showing strong growth over the past 10 years. Consequently, they were expected to be a good exemplar of a successful multi-channel strategy. Secondly, Buywell represents a typical multi-channel strategy firm, both in size and channel mix. The average number of channels for B2C business models is 4.2 channels (Day et al. 2002). Buywell uses four channels, making it representative of multi-channel organisations with respect to number of channels. Thirdly, Buywell has a relatively mature channel mix in comparison to most other multi-channel organisations within New Zealand. Furthermore, Buywell was a multi-channel organisation before wide-spread diffusion of the Internet, making them similar to multi-channel firms studied in the literature and increasing compatibility for SF matching.

\section{DATA COLLECTION AND ANALYSIS}

Data were collected in two phases. In the first phase, semi-structured interviews were held with five key managers: The Channel Campaign Manager, Distribution Centre Manager, Marketing Manager, IS Manager, and Managing Director. These five positions were chosen because they represent leadership positions in areas contributing to the organisation's multi-channel e-commerce strategy. Interviews sought to gain insight into the participants' understanding of how organisational elements influence the firm's e-commerce strategy. Interviewing five managers contributed to reliability by acting as verification on organisational memory and establishing a common understanding of multi-channel e-commerce strategy (Earl 1993). 
Interviews were transcribed in full and analysed using pattern matching with a list of categories based on the SFs identified from the literature. Additional categories, not identified from literature, were created as required. As we discussed earlier, we then conducted a post-hoc literature review to further explain our new categories, and identify the areas where we were aiming to make extensions to existing theory. Findings from this analysis were presented to Buywell management for verification and comment. Following that, we facilitated a focus group in which the management team responded to and elaborated on our findings.

\section{RESULTS}

As expected, all SFs were found to varying degrees. We have divided our results into three sections - areas where Buywell confirmed but did not extend the practices expected from e-commerce literature, areas where Buywell challenged or exceeded the practices suggested by existing ecommerce literature, and new factors we were not able to identify from existing literature. We first consider areas where Buywell confirmed existing theory.

\section{Confirmation of Existing Theory}

In these areas, Buywell's management found existing theory to be relevant to their business, but in our view, their business practices reflected, but did not significantly extend, existing theory.

\section{SF 1: Functional Integration}

In this area we found that Buywell followed the best practice identified in literature, but did not appear to significantly extend previous findings.

Buywell is extremely well integrated with a structure organised around functions rather than channels. The main three main functions used as the basis for the organisation structure are purchasing, logistics, and sales and marketing, called by Buywell "Buying Smarter", "Working Smarter", and "Selling Smarter". The Marketing Manager explained:

"We don't want to structure marketing in one silo, or one channel... it's all integrated within the role, and we work across the channels. We don't have a catalogue manager or an Internet marketing manager, we have a customer care manager or a loyalty manager, and they are there for the customer regardless of what channel."

Respondents confirmed Buywell had a strong, shared organisational philosophy. The General Manager explained:

“...they become accustomed to the 'Buywell Way' as we call it, from the customer service perspective..."

In summary, Buywell had a very high level of functional integration, and a clearly articulated shared identity and meaning across all functional departments.

\section{SF 2: Channel Synergy}

Channel synergy describes consistency of pricing and a seamlessness purchasing and communications experience across channels. In this area Buywell also demonstrated the best practice identified in literature. We did not find any insights from Buywell's practice that extended this individual factor significantly, although we did find a particularly close correlation between this factor and other factors, which is discussed later. The General Manager explained:

"We would confuse the heck out of those people if the website was totally different to the 
catalogue. So a lot of thought has gone into trying to provide consistency."

Marketing over the Internet is a lot cheaper than printing catalogues. To encourage customers to shop on the Internet, a free delivery incentive is offered. By contrast, catalogue orders incur a delivery charge. This provides an incentive without inconsistent pricing. The Channel Campaign manager explained:

"The only difference is free delivery on Internet orders. The actual product pricing is consistent."

In summary, Buywell's channels were found to be synergistic, providing a seamless communications and purchasing experience.

\section{SF 3: Brand Management}

Brand management includes portraying a consistent brand image and a track record of service delivery. The Marketing Manager commented:

"A lot of customers trust us with their credit card details. They think, 'Oh, that's Buywell, they're OK'. We're not a fly-by-night company or a dot-com. We're here to stay... I think it's the experience that the customer has in each channel. Are we consistent? Is our brand delivery consistent?"

Buywell has built a strong service brand by attention to quality control and consistency of service, building customer confidence across all channels. They are then able to leverage their brand across channels with a consistent brand image.

We found that maintaining a service brand in multi-channel retailing of experience goods such as apparel had particular challenges, and was highly dependant on internal quality processes to maintain the consistency and veracity of the virtual experience. This was identified as an additional success factor for Buywell, and is discussed in more detail later.

For these factors, functional integration, channel synergy, and brand management, the practice at Buywell confirmed existing theory. We now consider areas where findings from the Buywell case challenged or extended existing theory.

\section{Challenges or extensions to existing theory}

\section{SF 4: Information Management}

Information management involves keeping information up-to-date and systems integrated across channels. As expected, we found that Buywell had highly integrated information systems, but in this area we also found some interesting innovations and exceptions to current thinking.

Integrity of the database has been identified in previous research as a critical first step to successful management of customer relationships (Winer 2001). Buywell understands this and constructively uses database information in interactions with customers. The Channel Campaign Manager explained:

"The best thing about our environment is that we have a customer database that is just fantastic. We have the details and behaviour of every customer who shops with us. So we can recognise that we sent Mrs Jones an email and then she shopped two days later with us. We are fortunate in that respect. You can never underestimate the value that a database provides. We have a customer relationship manager now, and a CRM team. They are concerned with managing the database..."

Buywell have implemented several interesting innovations in information management. A major innovation is that Buywell strives to identify face-to-face customers in the physical retail stores by 
encouraging them to provide their customer number, or to register if they are new customers. This assists in providing completeness of data regardless of channel, and provides and extraordinarily rich picture of multi-channel shopper behaviour.

In an exception to much current research, we found that Buywell, despite their commitment to maintaining rich and accurate data, were wary of over-dependence on quantitative data and automated tools. We found that as well as data mining from the database, Buywell also had extensive processes in place for capturing qualitative information from customers and triangulating it with the quantitative data from their database. These processes are discussed in more detail in the section on "Active Scanning". Despite the high quality of their database, we found that Buywell were cautious about extensive use of their database for automated customer service, and web techniques such as one-to-one marketing techniques, and mass customisation. "The website isn't as good as the old CSR. With a CSR you [the customer] can have a conversation."

In summary, Buywell places great emphasis on keeping their database up-to-date and accurate. An interesting innovation is their ability to integrate data on customer buying behaviour in physical retail stores with data from other channels. Despite this, contrary to much current theory, Buywell are wary of over-dependence on the database. They value the insights gained from personal customer contacts very highly, and use qualitative data extensively to complement the outputs of their information systems.

\section{SF 5: Logistics Management}

Logistics management involves the processing of orders from multiple sources and provision of efficient and cost effective delivery, and is an essential component of a multi-channel strategy. As expected, we found that Buywell had highly integrated and effective logistics processes. We also found that Buywell had extended the best practices we were able to identify from literature for logistics management. In addition to attention to initial fulfilment, Buywell pro-actively managed the returns process. As well as internal efficiencies, Buywell had enhanced their logistics function with alliances. In addition, logistics excellence was used to further company growth. The General Manager commented:

"We've got an investment and infrastructure we can leverage. At one stage [a partner] had their own distribution centre, but we said 'hey this is complicating things, why don't you just come into here ",".

To provide basic operational efficiency, the distribution system is tightly integrated with the main order system. Orders from each channel are synthesised in a gateway before reaching the distribution centre. The Distribution Centre manager comments:

"To the distribution centre it's all the same. Orders comes in by a variety of means, but once the order is processed it comes down to the distribution centre warehouse management system and we don't know whether it's been a phone order, a mail order, or an Internet order."

Returns and service recovery are frequently a problem with e-commerce. At Buywell, pro-active management of the returns process extends the basic logistics process. Quality processes within the company reduce the return rate, which further enhances the efficiency of the logistics function. Buywell accepted that returns are a fact of life when selling apparel remotely, and aimed to manage them pro-actively:

"In New Zealand we do something we call Easy Returns. (The customer) only needs to affix a sticker that we send out to them to send an item back. They don't need to go the post office to pay for anything. Just put a sticker on and post it, and we debit their account $\$ 3.00$." 
As well as providing a service to customers, Buywell also use the return process as a source of market intelligence:

"On our returns form we have a section where people say why they are returning the item.

Obviously if $80 \%$ of people are saying the product is too long, we have a problem. So, comments are all analysed."

To enhance the efficiency of the logistics function, Buywell has formed an alliance with New Zealand's leading postal service provider which now has a branch collocated with Buywell. This improves cost-effectiveness of the delivery system.

We found that as well as providing internal efficiencies, Buywell's logistics capability has become a point of differentiation that has enabled growth. Several existing retailers with complementary products have formed co-branded partnerships with Buywell. These have included a children's wear company and a pharmaceuticals company who were interested in expanding their reach and channel range. The Buywell brand is used to give confidence in the logistics and fulfilment offered by the remote channels, while the original brand provides product quality confidence. This provides a winwin situation as the General manager explained:

"We could [act as an outsourcer] as a call centre business, but why do that... We prefer to share at the gross margin line... Why earn a dollar of someone when we could earn $\$ 3.50$ at the bottom line"

In summary, as suggested by previous research, Buywell are able to efficiently process orders from multiple sources. Its logistics system is tightly integrated with the ordering system. In our view, Buywell's practice extends existing our understanding of the logistics function in a multi-channel organisation selling non-commodity items. Buywell's products are experience goods and therefore more likely to be returned than commodity items, so they have extended the logistics function to provide pro-active management of the returns process. An operational alliance with a courier or postal services provider can improve cost-effectiveness. Finally, logistics capability has been leveraged to develop co-branded partnerships and contribute to company growth.

\section{SF 6: Customer Management}

We noted earlier that one aspect of Buywell's channel synergy is an integrated customer support through a contact centre. Integrated contact centres are relatively common, but rather than seeing contact centres as a necessary evil, measured by call closures, Buywell have developed their contact centre into the nerve-centre of the business. As part of their channel synergy, Buywell actively encouraged customers of all remote channels to use their contact centre remote channels. Buywell also engage in outbound communication to retain customers that have become inactive.

We found that Buywell's customer management practices had effectively mitigated one of the disadvantages often cited for selling experience goods remotely - lack of personalised selling. Once in touch with the contact centre, Buywell's customers are able to access empowered CSR's with excellent skills and resources for personalised selling, despite the lack of face-to-face contact.

For example, Buywell encourage customers to seek advice from CSRs during a purchase decision via the catalogue or website. This might involve getting an opinion from the Customer Service Representative (CSR) such as whether one piece of clothing matches another or thickness of a particular fabric. Portable racks along the walls of the contact centre display all apparel available from current catalogues, enabling CSRs to check products in response to questions. So popular is this system, that some customers request a specific CSR with whom they have formed a relationship. The Marketing Manager explained:

"CSRs can give information like the true colour of [an item of clothing], how good is it. A CSR can also tell the customer if two items of clothing go together...The CSR can be 
pro-active and say, "Hey, it's not exactly that colour, it's a little lighter - or darker. Do you still want it?" Or, "This size 10 is actually larger than a normal size 10. You may want to go down a size".

The contact centre is also a key source of real-time market intelligence. The process for gathering that intelligence is described in the section on "Active Scanning".

In summary, we found that Buywell extended existing understanding of customer management in multi-channel e-commerce, especially for non-commodity items such as clothing. In particular, considerable effort was made to empower CSR's to provide quality personalised selling.

\section{New insights into success factors for multi-channel e-commerce from an exemplar organisation}

This section describes aspects of Buywell's multi-channel strategy that were considered important to their success that we were not able to identify from previous studies in multi-channel e-commerce strategy.

\section{SF 7: Active Scanning}

To carry out market sensing, market-driven multi-channel organisations require the traditional e-commerce skills of customer management, including use of technology to manage customer relationships, process customer information, and offer enhanced customer service. But market sensing requires more it requires active scanning. Buywell leads best practice in being market driven through its ability to closely align strategic decisions to customer expectations. Customer expectations are garnered from extensive daily contact with them, as the General Manager observes:

"The great thing about this organisation is that we talk to every single customer - maybe not online - but we have a relationship with every customer either through the catalogue or And, further through the contact centre. It's quite unique."

"We talk to upwards of 8000 (customers) every day. So we get a lot of real time feedback about how we perform, across all our channels... major issues that are customer centric get dealt with very quickly by our contact centre manager, our sales and marketing manager, and our marketing department as appropriate. We spend a heck of a lot of time talking to our customers."

To be able to actively scan the market, employees must be motivated to pass to management the information gathered from customers. Buywell uses incentives and training of CSRs to provide the required motivation. The General Manager explains:

"...we have a structure in place where our Customer Service Reps have a reporting process through their team leaders to the contact centre manage, and that filters up through the organisation. We are a fairly flat organisation anyway; we are not a hugely hierarchical place. We are training our staff constantly, and starting to incentivise them to get a bit of competition going."

Information flows at Buywell are shown in Figure 1. Information is obtained from customer complaints and praise are gathered from website and catalogue customers primarily through the CSRs in the contact centres. These are passed on to team leaders and, where appropriate, to the Contact Centre Manager or the Sales and Marketing Manager, with significant information passing to the General Manager. 


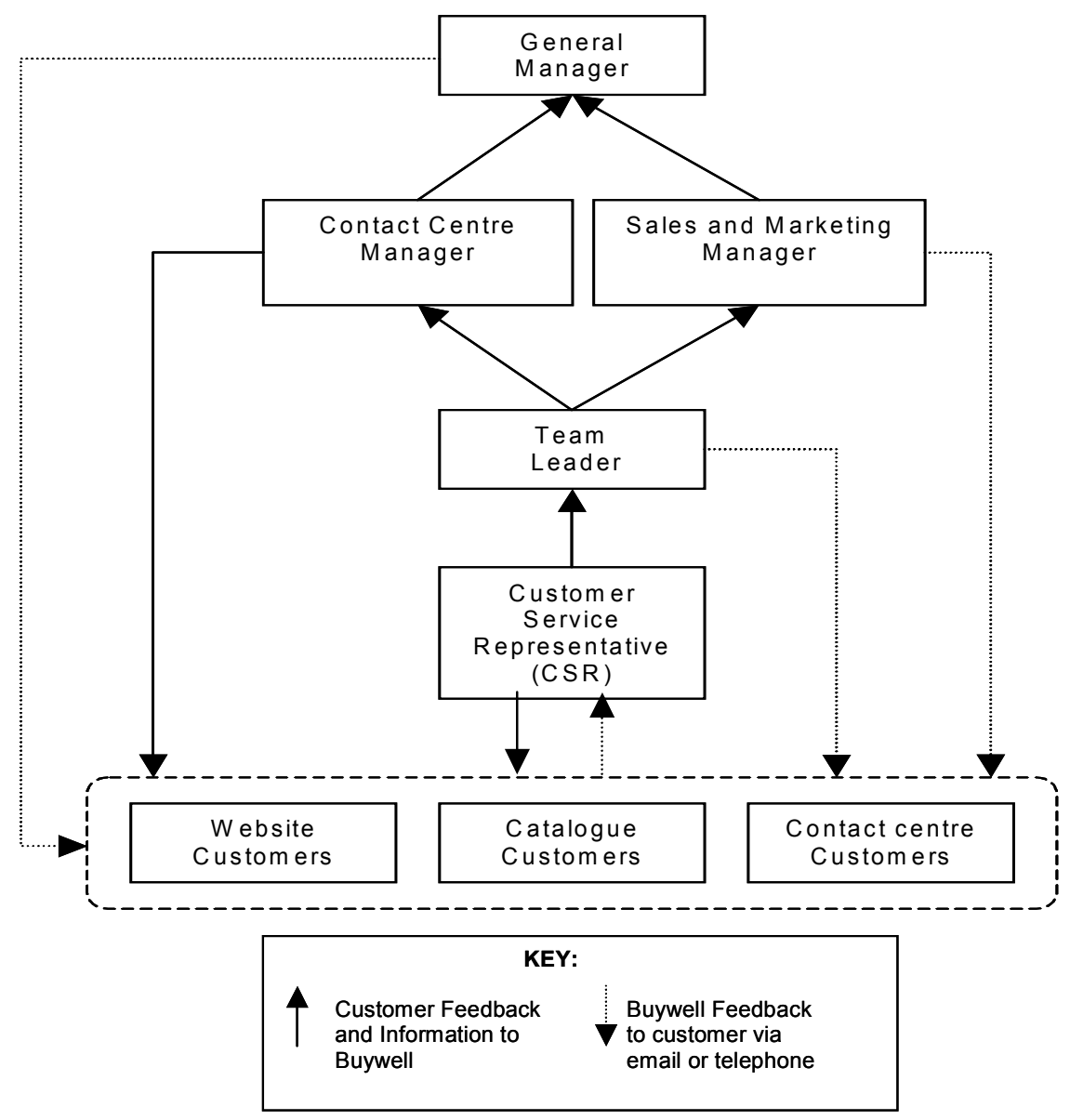

As a result of this flow of information through the organisation management gains insight into customer preferences, buying patterns, concerns, and areas for improvement. 
The contact centre does more than provide reactive customer management. The high level of customer contacts, and the personalisation and customer intimacy provided by the contact centre enable the practice of active scanning, as shown in Figure 2. The incentives and value placed by the senior management on the market scanning provided by the contact centre further empowers and enhances the process of customer management. This creates a virtuous circle that provides a continuous flow of rich, real-time market information.

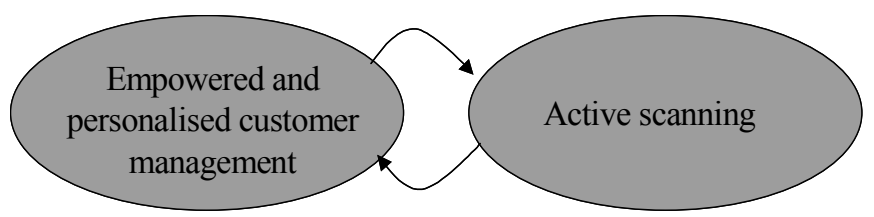

Figure 2: "Virtuous circle" of empowered customer management and active scanning

In summary, Buywell have complemented their operational management of customer relationships across multi-channels with a sophisticated market-sensing mechanism, which is used to pass flows of information from customers to management.

\section{SF 8: Process engineering}

We were not able to identify any studies of multi-channel e-commerce that specifically discussed this factor. This seems to be particularly relevant to the sale of non-commoditised items. Goods such as apparel and home-wares have been considered difficult to sell over the Internet because of the lack of ability to "touch and feel" (Zeng et al. 2003). We found that an important part of the Buywell brand experience was extensive quality controls to ensure consistency and veracity (for example, in colour and texture) between the virtual experience and the actual goods.

Buywell have a whole department dedicated to product consistency, particularly with respect to fit. For example:

"We have different sized people who will try on garments. Like, we'll have a perfect size 12 who will try on a dress... And that is what we base our sizes on."

All Buywell's products are made to order to using measurements that are specific to the body shape of their target market, Australasia. So, there is a good initial likelihood of fit. In a market where sizing of women's apparel is extremely inconsistent, this offers confidence in the remote buying experience. The Marketing Manager explains:

"I can be a size 10 in one retail store, an 8 in another store or a 12 in another. Whereas at Buywell we work really hard (on sizing consistency) and decrease returns by doing that. Our size 10 is this size waist, this size hips, and that's for New Zealand. So we have Buywell measurements."

Attention to consistency increases customer confidence, and contributes to the brand image and the likelihood of repeat purchasing.

In addition to consistency, a commonly raised objection to purchasing apparel remotely is the inability to check fabric colour and quality. Buywell have quality control processes to ensure a realistic virtual depiction of the products, especially for catalogue production. Quality controls are 
exercised at all stages of the imaging and printing process. The Marketing Manager describes part of the process:

"We have an established relationship with an imaging company. They are the ones who make sure (images) are correct. ...And we'll have samples of the clothing styles in every colour, so the imaging company can compare - they can grab the garment and put it against the image."

In summary, attention to product consistency, and to veracity between the virtual presentation of products and the real-world versions is a key aspect of Buywell's multi-channel strategy that has received little or no attention in previous studies. This factor directly supports brand management, and also contributes indirectly to excellence in other areas, such as logistics, by reducing the return rate. This has significant implications for multi-channel retailers of other non-commodity items.

\section{SUMMARY}

Buywell showed elements of each of the original SFs we identified from the literature: functional integration, channel synergy, brand management, information management, logistics, customer management and active scanning. For functional integration, channel synergy and brand management, we found that Buywell confirmed but did not significantly extend the findings from previous studies. For logistics and customer management Buywell's practices extended the findings we were able to identify from previous studies, in particular by creating added value for the business as well as providing operational efficiency. For information management, we found that Buywell were able to capture information about most face-to-face customer contacts, which provided a particularly rich picture of customer multi-channel behaviour. Despite this, contrary to the findings of some previous research, Buywell were wary about excessive dependence on their database at the expense of personal and qualitative insights and customer contacts. Active scanning, and process engineering to provide consistency and veracity of experience were new factors added as a result of this study. Active scanning is a concept from marketing literature, but we were unable to find any studies that related it specifically to multi-channel e-commerce. We also found relatively no previous literature considering the importance process engineering to provide consistency and veracity between real and virtual experience. This is particularly relevant to products such as apparel.

Table 1 provides a summary of the elements of each SF found in Buywell and their relationship to previous research in multi-channel e-commerce strategy.

\section{DISCUSSION}

The findings of this case study confirm the criticality of SFs identified from the literature in a multi-channel retail apparel firm. Some additional insights are offered to factors previously identified by research, and two new success factors - active scanning, and process engineering, to provide consistency and veracity of experience, are proposed.

Several limitations of this study should be considered. First, the channels tested are a subset of channels available to retailers. The study focussed on mail-order catalogue, Internet website, contact centre, and physical retail stores. Channels not included, though of increasing importance, include mobile technologies and in-store kiosks. Second, this was a single case study, so the findings need to be further investigated in firms with characteristics similar to the case site.

Implications for future research may be drawn from these limitations. There appears to be some overlap and some correlation between the SFs. Future research may determine the importance of each SF, and how each SF is related to others in its impact on firm performance. 
Although Buywell have a long and successful history as a multi-channel organisation, their Internet channel is still at a relatively early stage of development. Many multi-channel strategies are transferable across channels, but not all. Future research involving a longitudinal study of the development of Buywell's Internet could provide insights into how a successful multi-channel ecommerce strategy evolves as the Internet channel matures.

Further, our study suggests that researchers in e-commerce strategy have largely ignored importance of process engineering. Existing theory from other fields, such as Marketing, Diffusion of Innovation, and Information Technology implementation could be examined for relevance and fit to e-commerce strategy.

\section{CONCLUSIONS}

Several contributions emerge from this research. We provide eight success factors for multi-channel e-commerce strategies incorporating the Internet, mail-order catalogue, contact centre, and physical retail stores. We make a theoretical contribution by showing how customer management can be extended to market sensing in a multi-channel business model, and arguing for the importance of process engineering in providing a consistent experience between real and virtual channels. We provide best practice insights from an organisation that has proved highly successful in selling experience goods, a category often considered to be difficult to sell over the Internet.

In an era of increased customer purchasing options, the challenge is to keep customers within the channel mix of the organisation. Buywell showed how this could be done through a focus on customers, a focus on process, and skilful use of technology.

This research suggests that success factors in multi-channel e-commerce are not a "laundry list" of independent factors, but a set of highly interdependent processes and practices. Further research is required to model these interdependencies. Success factors may vary with the product line and the channel mix, Buywell sell mainly experience goods, and the majority of their products are sold through remote channels. 
Table 1: Summary of Success Factor Elements

\begin{tabular}{|c|c|c|c|}
\hline Success Factor & Sources & $\begin{array}{l}\text { Strategies that } \\
\text { CONFIRM existing } \\
\text { theory }\end{array}$ & $\begin{array}{l}\text { Strategies that } \\
\text { CHALLENGE } \\
\text { or EXTEND } \\
\text { existing theory }\end{array}$ \\
\hline \multicolumn{4}{|c|}{ Confirmation of Existing Theory } \\
\hline $\begin{array}{l}\text { Functional } \\
\text { integration }\end{array}$ & $\begin{array}{l}\text { Barua, Konana, Whinston \& } \\
\text { Yin (2001); Ghoshal \& Gratton } \\
\text { (2002); Goersch (2002); Gulati } \\
\text { \& Garino (2000); Lee (2001); } \\
\text { Schoenbachler \& Gordon } \\
\text { (2002); Steinfield (2002); } \\
\text { Westerman (2002); Willcocks } \\
\text { \& Plant (2001). }\end{array}$ & $\begin{array}{l}\text { Shared organisational } \\
\text { functions } \\
\text { Shared identity and } \\
\text { meaning }\end{array}$ & none \\
\hline Channel synergy & $\begin{array}{l}\text { Goersch (2002); } \\
\text { Kaufman-Scarborough \& } \\
\text { Lindquist (2002); } \\
\text { Schoenbachler \& Gordon } \\
\text { (2002); Porter (2001); Reardon } \\
\text { \& McCorkle (2002); Simons } \\
\text { (2001); Steinfield (2002). }\end{array}$ & $\begin{array}{l}\text { Seamlessness of } \\
\text { experience } \\
\text { Consistent pricing }\end{array}$ & none \\
\hline $\begin{array}{l}\text { Brand } \\
\text { Management }\end{array}$ & $\begin{array}{l}\text { Bitner et al (2002), Goersch, } \\
\text { 2002; Kocas (2003); } \\
\text { Schoenbachler \& Gordon, } \\
\text { (2002); Willcocks \& Plant } \\
(2001) \text {. }\end{array}$ & $\begin{array}{l}\text { Brand attribute } \\
\text { leverage } \\
\text { Consistent brand } \\
\text { image } \\
\text { Service delivery track } \\
\text { record }\end{array}$ & none \\
\hline
\end{tabular}

\begin{tabular}{|c|c|c|c|}
\hline \multicolumn{4}{|c|}{ Challenges or extensions to existing theory } \\
\hline $\begin{array}{l}\text { Information } \\
\text { Management }\end{array}$ & $\begin{array}{l}\text { Barua, Konana, Whinston \& } \\
\text { Yin (2001); Goersch, 2002); } \\
\text { Lee et al (2001); Weill \& } \\
\text { Vitale (2002); Willcocks \& } \\
\text { Plant (2001); Zettelmeyer } \\
(2000) .\end{array}$ & $\begin{array}{l}\text { Data integrity } \\
\text { Systems } \\
\text { integration }\end{array}$ & $\begin{array}{l}\text { Ability to identify face-to- } \\
\text { face shoppers and integrate } \\
\text { with data from other } \\
\text { channels } \\
\text { Integration of qualitative } \\
\text { and quantitative data about } \\
\text { customers }\end{array}$ \\
\hline Logistics & $\begin{array}{l}\text { Lee \& Whang (2001); Pyke, } \\
\text { Johnson \& Desmond (2001). }\end{array}$ & $\begin{array}{l}\text { Ability to process } \\
\text { orders from } \\
\text { multiple sources }\end{array}$ & $\begin{array}{l}\text { Partnership with postal } \\
\text { services provider } \\
\text { Leveraging logistics } \\
\text { capability to create } \\
\text { alliances and growth } \\
\text { Active management of } \\
\text { returns and return rate }\end{array}$ \\
\hline
\end{tabular}




\begin{tabular}{|l|l|l|l|}
\hline $\begin{array}{l}\text { Customer } \\
\text { Management }\end{array}$ & Barua, Konana, Whinston \& & Customer service & Remote personalised \\
& Yin (2001); Lee (2001); & Customer & merchandising \\
& Kaufman-Scarborough \& & information & Empowered customer \\
& Lindquist (2002); & processing & management \\
& $\begin{array}{l}\text { Schoenbachler \& Gordon } \\
\text { (2002); Simons (2001); }\end{array}$ & Timely response & "Virtuous circle" of \\
& to e-mail & $\begin{array}{l}\text { empowered customer } \\
\text { Willcocks \& Plant (2001). }\end{array}$ & \\
& & & management and active \\
\end{tabular}

\begin{tabular}{|l|l|l|l|}
\hline \multicolumn{2}{|l|}{ New insights into success factors for multi-channel e-commerce from an exemplar organisation } \\
\hline $\begin{array}{l}\text { Active } \\
\text { scanning }\end{array}$ & $\begin{array}{l}\text { Day (1994); Day \& Hubbard } \\
(2002) .\end{array}$ & Active scanning & $\begin{array}{l}\text { A centralised contact centre } \\
\text { providing rich and intimate } \\
\text { personal contact supported } \\
\text { by sophisticated processes to } \\
\text { capture customer feedback } \\
\text { can provide active market } \\
\text { scanning for a multi-channel } \\
\text { organisation }\end{array}$ \\
\hline $\begin{array}{l}\text { Process } \\
\text { engineering }\end{array}$ & none & $\begin{array}{l}\text { Internal processes } \\
\text { to ensure the } \\
\text { consistency and } \\
\text { veracity of real and } \\
\text { virtual experience }\end{array}$ & $\begin{array}{l}\text { Quality internal processes } \\
\text { are required for multi- } \\
\text { channel retailing of non- } \\
\text { commodity items }\end{array}$ \\
\hline
\end{tabular}

Mary Tate, Brent Coker, and Beverley Hope (C) 2004. The authors assign to ACIS and educational and non-profit institutions a non-exclusive licence to use this document for personal use and in courses of instruction provided that the article is used in full and this copyright statement is reproduced. The authors also grant a non-exclusive licence to ACIS to publish this document in full in the Conference Papers and Proceedings. Those documents may be published on the World Wide Web, CD-ROM, in printed form, and on mirror sites on the World Wide Web. Any other usage is prohibited without the express permission of the authors.

\section{REFERENCES}

Balabanis, G., and Reynolds, N.L. "Consumer attitudes towards multi-channel retailer's Web sites: The role on involvement, brand attitude, Internet knowlege and visit duration," Journal of Business Strategies (18:2) 2001.

Barua, A., Konana, P., Whinston, A.B., and Yin, F. "Driving e-business excellence," MIT Sloan Management Review (43:1) 2001.

Bitner, M.J., Brown, S., and Meuter, M.L. "Technology infusion in service encounters," in: Academy of Marketing Science Journal, 2000.

Bitner, M.J., Ostrom, A.L., and Meuter, M.L. "Implementing successful self-service technologies," Academy of Management Executive (16:4) 2002.

Day, G.S. "The capabilities of market driven organisations," Journal of Marketing Management (58:4) 1994.

Day, G.S., and Hubbard, K.J. "Customer relationships go digital," Business Strategy Review (14:1) 2002. 
Earl, M.J. "Experiences in strategic information systems planning," MIS Quarterly (17:1) 1993.

Forrester "Capturing Cross Channel Dollars," 2002.

Ghoshal, S., and Gratton, L. "Integrating the enterprise," MIT Sloan Management Review (44:1) 2002.

Goersch, D. "Multi-channel Integration and its implications for retail Web-sites," European Conference on Information Systems, Gdansk, Poland, 2002.

Gulati, R., and Garino, J. "Get the right mix of bricks and clicks," Harvard Business review (78:3) 2002.

Kaufman-Scarborough, C., and Lindquist, J.D. "E-shopping in a multiple-channel environment," Journal of Consumer Marketing (19:4) 2002.

Kocas, C. "Evolution of prices in electronic markets under diffusion of price-comparison shopping," Journal of Management Information Systems (19:3) 2003.

Lee, H.L., and Whang, S. "Winning the last mile of e-commerce," MIT Sloan Management Review (42:4) 2001, pp 54-62.

Porter, M. "Strategy and the Internet," Harvard Business review (79:3) 2001.

Pyke, D.F., Johnson, M.E., and Desmond, P. "E-fulfillment: It's harder than it looks," Supply Chain Management Review (January/February) 2001, pp 26-32.

Reardon, J., and McCorkle, D.E. "A consumer model for channel switching behaviour," International Journal of Retailing and Distribution Management (30:4) 2002.

Schneider, G., and Perry, J. Electronic Commerce Thomson Learning, Boston MA, 2001.

Schoenbachler, D.D., and Gordon, G.L. "Multi-channel shopping: understanding what drives channel choice.," Journal of Consumer Marketing (19:1) 2002, pp 42-53.

Shop.org "The Multi-Channel Retail Report 2.0," 2001.

Simons, L.P.A., Steinfield, C., and Bouwman, H. "Strategic Position of the web in a multi-channel market approach," Internet Research: electronic Networking Applications and Policy (12:4) 2002.

Steinfield, C., Bouwman, H., and Adelaar, T. "The dynamic of click-and mortar electronic commerce: Opportunities and management strategies," International Journal of Electronic Commerce (7:1) 2002.

Weill, P., and Vitale, M. "What IT infrastructure capabilities are needed to implement e-business models," MIS Quarterly Executive (1:1) 2002.

Westerman, G. "Mixing bricks with clicks: Organisation design for busineness-to-consumer electronic commerce in incumbent retailers," International Conference on Information Systems, Barcelona, Spain, 2002.

Willcocks, L.P., and Plant, R. "Pathways to e-business leadership: Getting from bricks to clicks," MIT Slaon Management Review (42) 2001a.

Willcocks, L.P., and Plant, R. "Pathways to e-business leadership: Getting from bricks to clicks," MIT Sloan Management Review (42) 2001b, pp 50-59.

Winer, R.S. "A framework for customer relationship management," California Management Review (43:4) 2001, pp 89-104.

Yin, R.K. Applications of case study research Sage Publications, Thousand Oaks, CA, 1993.

Zeng, M., and Reinartz, W. "Beyond online search: The road to profitability," California Management Review (43:4) 2003. 